\title{
Letter on Monetary Policy
}

\author{
TO SENATOR WILLIAM PROXMIRE
}

From ARTHUR F. BURNS

\begin{abstract}
Senator William Proxmire, Wisconsin, is Vice Chairman of the Joint Economic Committee. Arthur F. Burns is Chairman of the Board of Governors of the Federal Reserve System.
\end{abstract}

The Honorable William Proxmire

United States Senate

Washington, D. C.

\section{Dear Senator Proxmire:}

I am writing in further response to your letter of September 17, 1973, which requested comments on certain criticisms of monetary policy over the past year.

As stated in your letter, the criticisms are: (1) "that there was too much variation from time to time in the rate of increase in the money supply, that monetary policy was too erratic, too much characterized by stops and starts"; and (2) "that the money supply had increased much too much last year, in fact that the increase would have been too much even if we had been in the depths of a recession instead of enjoying a fairly vigorous economic expansion."

These criticisms involve basic issues with regard to the role of money in the economy, and the role that the money supply should play in the formulation and execution of monetary policy. These issues, along with the specific points you raise, require careful examination.

\section{Criticism of Out public Policies}

During the past two years the American economy has experienced a substantial measure of prosperity. Real output has increased sharply, jobs have been created for millions of additional workers, and total personal income - both in dollars and in terms of real purchasing power - has risen to the highest levels ever reached.

Yet the prosperity has been a troubled one. Price increases have been large and widespread. For a time, the unemployment rate remained unduly high. Interest rates have risen sharply since the spring of 1972 . Mortgage money has recently become difficult to obtain in many communities. And confidence in the dollar at home and abroad has at times wavered.

Many observers have blamed these difficulties on the management of public economic policies. Certainly, the Federal budget - despite vigorous efforts to hold expenditures down - continued in substantial deficit. There has also been an enormous growth in the activities of Federally-sponsored agencies which, although technically outside the budget, must still be financed. The results of efforts to control wages and prices during the past year have been disappointing. Partial decontrol in early 1973 and the subsequent freeze failed to bring the results that were hoped for. 
Monetary policy has been criticized on somewhat contradictory counts - for being inflationary, or for permitting too high a level of interest rates, or for failing to bring the economy back to full employment, or for permitting excessive shortterm variations in the growth of the money supply, and so on.

One indication of dissatisfaction with our public policies was provided by a report, to which you refer in your letter, on a questionnaire survey conducted by the National Association of Business Economists. of the respondents, 38 per cent rated fiscal policy "over the past year" as "poor"; 41 per cent rated monetary policy "over the past year" as "poor"; only 14 per cent felt that the wage-price controls under Phase IV were "about right." If this sampling is at all indicative, the public policies on which we have relied are being widely questioned. Many members of the above group, in fact, went on record for a significant change in fiscal policy. In response to a question whether they favored a variable investment tax credit, 46.5 per cent said "yes," 40 per cent said "no," and 13.5 per cent expressed "no opinion."

Let me turn now to the questions raised in your letter and in some other recent discussions about monetary policy. I shall discuss, in particular, the role of money supply in the conduct of monetary policy; the extent and significance of variability in the growth of the money supply; and the actual behavior of the money supply during 1972-73.

\section{Role of Money Supply}

For many years economists have debated the role of the money supply in the performance of economic systems. One school of thought, often termed "monetarist," claims that changes in the money supply inAuence very importantly, perhaps even decisively, the pace of economic activity and the level of prices. Monetarists contend that the monetary authorities should pay principal attention to the money supply, rather than to other inancial variables such as interest rates, in the conduct of monetary policy. They also contend that fiscal policy has only a small independent impact on the economy.

Another school of thought places less emphasis on the money supply and assigns more importance to the expenditure and tax policies of the Federal Government as factors infuencing real eonomic activity and the level of prices. This school emphasizes the need for monetary policy to be concerned with interest rates and with conditions in the money and capital markets. Some economic activities, particularly residential building and state and local government construction, depend heavily on borrowed funds, and are therefore influenced greatly by changes in the cost and availability of credit. In other categories of spending - such as business investment in fixed capital and inventories, and consumer purchases of durable goods - credit conditions play a less decisive role, but they are nonetheless important.

Monetarists recognize that monetary policy affects private spending in part through its impact on interest rates and other credit terms. But they believe that primary attention to the growth of the money supply will result in a more appropriate monetary policy than would attention to conditions in the credit markets.

Needless to say, monetary policy is - and has long been - a controversial subject. Even the monetarists do not speak with one voice on monetary policy. some influential monetarists believe that monetary policy should aim strictly at maintaining a constant rate of growth of the money supply. However, what that constant should be, or how broadly the money supply should be defined, are matters on which monetarists still differ. And there are also monetarists who would allow some-but infrequent-changes in the rate of growth of the money supply, in accordance with changing economic conditions.

It seems self-evident that adherence to a rigid growth rate rule, or even one that is changed infrequently, would practically prevent monetary policy from playing an active role in economic stabilization. Monetarists recognize this. They believe that most economic disturbances tend to be self-correcting, and they therefore argue that a constant or nearly constant rate of growth of the money supply would result in reasonably satisfactory economic performance.

But neither historical evidence, nor the thrust of explorations in business-cycle theory over a long century, give support to the notion that our economy is inherently stable. On the contrary, experience has demonstrated repeatedly that blind reliance on the self-correcting properties of our economic system can lead to serious trouble. Discretionary economic policy, while it has at times led to mistakes, has more often proved reasonably successful. The disappearance of business depressions, which in earlier times spelled mass unemployment for workers and mass bankrupt- 
cies for businessmen, is largely attributable to the stabilization policies of the last thirty years.

The fact is that the internal workings of a market economy tend of themselves to generate business fluctuations, and most modern economists recognize this. For example, improved prospects for profits often spur unsustainable bursts of investment spending. The How of personal income in an age of affluence allows ample latitude for changes in discretionary expenditures and in savings rates. During a business-cycle expansion various imbalances tend to develop within the economy - between aggregate inventories and sales, or between aggregate business investment in fixed capital and consumer outlays, or between average unit costs of production and prices. Such imbalances give rise to cyclical movements in the economy. Flexible fiscal and monetary policies, therelore, are often needed to cope with undesirable economic developments, and this need is not diminished by the fact that our available tools of economic stabilization leave something to be desired.

There is general agreement among economists that, as a rule, the effects of stabilization policies occur gradually over time, and that economic forecasts are an essential tool of policy making. However, no economist - or school of economics - has a monopoly on accurate forecasting. At times, forecasts based largely on the money supply have turned out to be satisfactory. At other times, such forecasts have been quite poor, mainly because of unanticipated changes in the intensity with which the existing money stock is used by business firms and consumers.

Changes in the rate of turnover of money have historically played a large role in economic fluctuations, and they continue to do so. For example, the narrowly-defined money stock - that is, demand deposits plus currency in public circulation - grew by 5.7 per cent between the fourth quarter of 1969 and the fourth quarter of 1970 . But the turnover of money declined during that year, and the dollar value of GNP rose only 4.5 per cent. In the following year, the growth rate of the money supply increased to 6.9 per cent, but the turnover of money picked up briskly and the dollar value of GNP accelerated to 9.3 per cent. The movement out of recession in 1970 into recovery in 1971 was thus closely related to the greater intensity in the use of money. Occurrences such as this are very common because the willingness to use the existing stock of money, expressed in its rate of turnover, is a highly dynamic force in economic life.
For this as well as other reasons, the Federal heserve uses a blend of forecasting techniques. The behavior of the money supply and other financial variables is accorded careful attention. So also are the results of the most recent surveys on plant and equipment spending, consumer attitudes, and inventory plans. Recent trends in key producing and spending sectors are analyzed. The opinions of businessmen and outside economic analysts are canvassed, in part through the nationwide contacts of Federal Reserve Banks. And an assessment is made of the probable course of fiscal policy, also of labor-market and agricultural policies, and their effects on the economy.

Evidence from all these sources is weighed. Efforts are also made to assess economic developments through the use of large-scale econometric models. An eclectic approach is thus taken by the Federal Reserve, in recognition of the fact that the state of economic knowledge does not justify reliance on any single forecasting technique. As economic research has cumulated, it has become increasingly clear that money does indeed matter. But other financial variables also matter.

In recent years, the Federal Reserve has placed somewhat more emphasis on achieving desired growth rates of the monetary aggregates, including the narrowly-defined money supply, in its conduct of monetary policy. But we have continued to give careful attention to other financial indicators, among them the level of interest rates on mortgages and other loans and the liquidity position of financial institutions and the general public. This is necessary because the economic implications of any given monetary growth rate depend on the state of liquidity, the attitudes of businessmen, investors, and consumers toward liquidity, the cost and availability of borrowed funds, and other factors. Also, as the nation's central bank, the Federal Reserve can never lose sight of its role as a lender of last resort, so that financial crises and panics will be averted.

I recognize that one advantage of maintaining a relatively stable growth rate of the money supply is that a partial offset is thereby provided to unexpected and undesired shifts in the aggregate demand for goods and services. There is always some uncertainty as to the emerging strength of aggregate demand. If money growth is maintained at a rather stable rate, and aggregate demand turns out to be weaker than is consistent with the nation's economic objectives, in- 
terest rates will tend to decline and the easing of credit markets should help to moderate the undesired weakness in demand. Similarly, if the demand for goods and services threatens to outrun productive capacity, a rather stable rate of monetary growth will provide a restraining influence on the supply of credit and thus tend to restrain excessive spending.

However, it would be unwise for monetary policy to aim at all times at a constant or nearly constant rate of growth of money balances. The money growth rate that can contribute most to national objectives will vary with economic conditions. For example, if the aggregate demand for goods and services is unusually weak, or if the demand for liquidity is unusually strong, a rate of increase in the money supply well above the desirable long-term trend may be needed for a time. Again, when the economy is experiencing severe cost-push inflation, a monetary growth rate that is relatively high by a historical yardstick may have to be tolerated for a time. If money growth were severely constrained in order to combat the element of inflation resulting from such a cause, it might well have seriously adverse effects on production and employment. In short, what growth rate of the money supply is appropriate at any given time cannot be determined simply by extrapolating past trends or by some preconceived arithmetical standard.

Moreover, for purposes of conducting monetary policy, it is never safe to rely on just one concept of money - even if that concept happens to be fashionable. A variety of plausible concepts merit careful attention, because a number of financial assets serve as a convenient, safe, and liquid store of purchasing power.

The Federal Reserve publishes data corresponding to three definitions of money, and takes all of them into account in determining policy. The three measures are: (a) the narrowly-defined money stock $\left(\mathrm{M}_{1}\right)$, which encompasses currency and demand deposits held by the nonbank public; (b) a more broadlydefined money stock $\left(\mathrm{M}_{2}\right)$, which also includes time and savings deposits at commercial banks (other than large negotiable time certificates of deposit); (c) a still broader definition $\left(\mathrm{M}_{3}\right)$, which includes savings deposits at mutual savings banks and savings and loan associations. A definition embracing other liquid assets could also be justified - for example, one that would include large-denomination negotiable time certificates of deposit, U.S. savings bonds and Treasury bills, commercial paper, and other short-term money market instruments.

There are many assets closely related to cash, and the public can switch readily among these assets. However money may be defined, the task of determining the amount of money needed to maintain high employment and reasonable stability of the general price level is complicated by shifting preferences of the public for cash and other financial assets.

\section{Variability of Money Supply Crouth}

In the short run, the rate of change in the observed money supply is quite erratic, and cannot be trusted as an indicator of the course of monetary policy. This would be so even if there were no errors of measurement.

The record of hearings held by the Joint Economic Committee on June 27, 1973 includes a memorandum which I submitted on problems encountered in controlling the money supply. As indicated there, weekto-week, month-to-month, and even quarter-to-quarter fluctuations in the rate of change of money balances are frequently influenced by international flows of funds, changes in the level of U.S Government deposits, and sudden changes in the public's attitude towards liquidity. Some of these variations appear to be essentially random - a product of the enormous $\mathrm{ebb}$ and flow of funds in our modem economy.

Because the demands of the public for money are subject to rather wide short-term variations, efforts by the Federal Reserve to maintain a constant growth rate of the money supply could lead to sharp short-run swings in interest rates and risk damage to financial markets and the economy. Uncertainties about financing costs could reduce the fluidity of markets and increase the costs of financing to borrowers. In addition, wide and erratic movements of interest rates and financial conditions could have undesirable effects on business and consumer spending. These adverse effects may not be of major dimensions, but it is better to avoid them.

In any event, for a variety of reasons explained in the memorandum for the Joint Economic Committee, to which I have previously referred, the Federal Rew serve does not have precise control over the money supply. To give one example, a significant part of the money supply consists of deposits lodged in nonmember banks that are not subject to the reserve 
requirements set by the Federal Reserve. As a result there is some slippage in monetary control. Furthermore, since deposits at nonmember banks have been reported for only two to four days in a year, in contrast to daily statistics for member banks, the data on the money supply - which we regularly present on a weekly, monthly, and quarterly basis - are estimates rather than precise measurements. When the infrequent reports from nonmember banks become available, they often necessitate considerable revisions of the money supply figures. In the past two years, the revisions were upward, and this may happen again this year.

Some indication of the extent of short-term variations in the recorded money supply is provided below. Table I shows the average and maximum deviations (without regard to sign) of $\mathrm{M}_{1}$ from its average annual growth rate over a three and a half year period. As would be expected, the degree of variation diminishes as the time unit lengthens; it is much larger for monthly than for quarterly data, and is also larger for quarterly than for semi-amnual data.

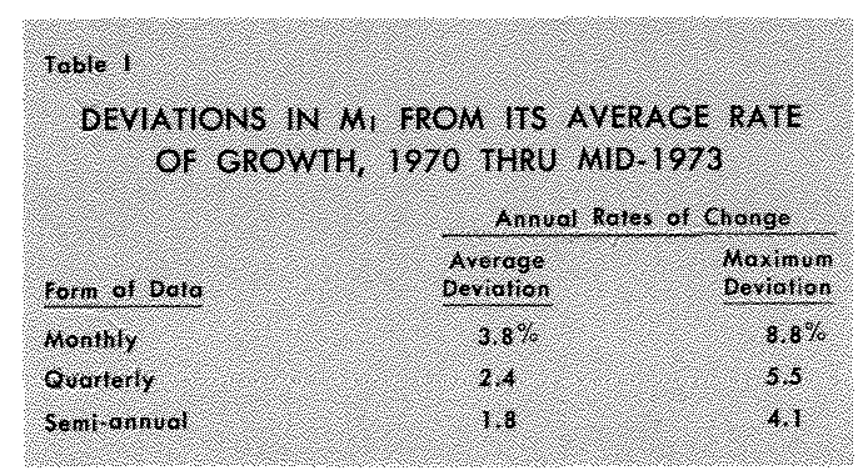

In our judgment, there need be little reason for concern about the short-run variations that occur in the rate of change in the money stock. Such variations have minimal effects on the real economy. For one thing, the outstanding supply of money is very large. It is also quite stable, even when the short-run rate of change is unstable. This October the average outstanding supply of $\mathrm{M}_{1}$, seasonally adjusted, was about $\$ 264$ billion. On this base, a monthly rise or fall in the money stock of even $\$ 2.5$ billion would amount to only a 1 per cent change. But when such a temporary change is expressed as an annual rate, as is now commonly done, it comes out as about 12 per cent and attracts attention far beyond its real significance.

The Federal Reserve research staff has investigated carefully the economic implications of variability in $\mathrm{M}_{1}$ growth. The experience of the past two decades suggests that even an abnormally large or abnormally small rate of growth of the money stock over a period up to six months or so has a negligible influence on the course of the economy-provided it is subsequently offset. Such short-run variations in the rate of change in the money supply may not at all reflect Federal Reserve policy, and they do not justify the attention they often receive from financial analysts.

The thrust of monetary policy and its probable effects on economic activity can only be determined by observing the course of the money supply and of other monetary aggregates over periods lasting six months or so. Even then, care must be taken to measure the growth of money balances in ways that temper the influence of short-term variations. For example, the growth of money balances over a quarter can be measured from the amount outstanding in the last month of the preceding quarter to the last month of the current quarter, or from the average amount outstanding during the preceding quarter to the average in the current quarter. The first measure captures the latest tendencies in the money supply, but may be distorted by random changes that have no lasting significance. The second measure tends to average out temporary fluctuations and is comparable to the data provided on a wide range of non-monetary economic variables, such as the gross national product and related measures.

A comparison of these two ways of measuring the rate of growth in $\mathrm{M}_{1}$ is shown in Table II for successive quarters in 1972 and 1973. The first column, labeled $M$, shows annual rates calculated from endmonths of quarters; the second columm, labeled $Q$, shows annual rates calculated from quarterly averages.

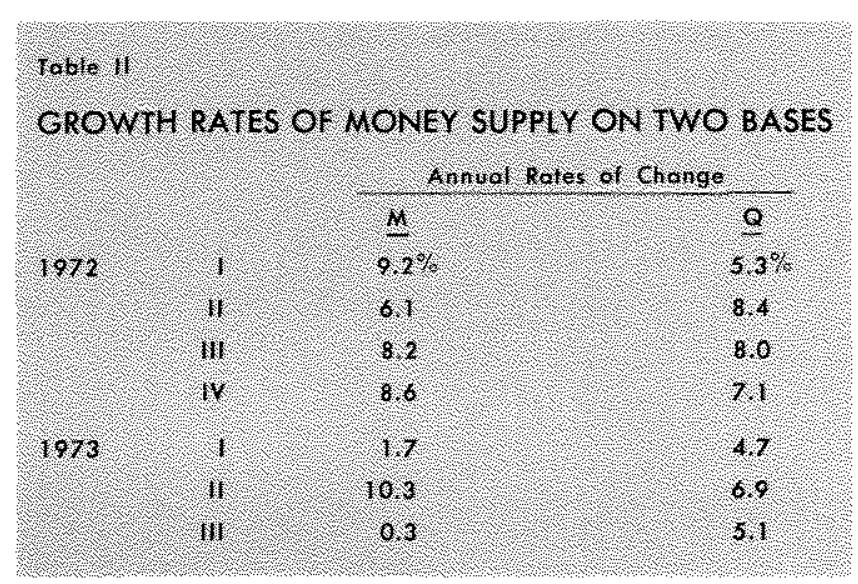

As may be seen, the quarterly averages disclose much more clearly the developing trend of monetary restraint - which, in fact, began in the second quarter of 1972. Also, the growth of $M_{1}$, which on a month- 
end basis appears very erratic in the first three quarters of 1973 , is much more stable on a quarterly average basis. For example, while the level of $\mathrm{M}_{1}$ did not expand significantly between June and September, the quarterly average figures indicate further sizable growth in the third quarter. For purposes of economic analysis, it is an advantage to recognize that the money available for use was appreciably larger in the third quarter than in the second quarter.

\section{ixperience of $1972-73$}

During 1972, it was the responsibility of the Federal Reserve to encourage a rate of economic expansion adequate to reduce unemployment to acceptable levels. At the same time, despite the dampening effects of the wage-price control program, inflationary pressures were gathering. Monetary policy, therefore, had to balance the twin objectives of containing inflationary pressures and encouraging economic growth. These objectives were to some extent conflicting, and monetary policy alone could not be expected to cope with both problms. Continuation of an effective wageprice program and a firmer policy of fiscal restraint were urgently needed.

The narrowly-defined money stock increased 7.4 per cent during 1972 (measured from the fourth quarter of 1971 to the fourth quarter of 1972). Between the third quarter of 1972 and the third quarter of 1973 , the growth rate was 6.1 per cent. By the first half of 1973 , the annual growth rate had declined to 5.8 per cent, and a further slowing occurred in the third quarter.

Evaluation of the appropriateness of these growth rates would require full analysis of the economic and financial objectives, conditions, and policies during the past two years, if not longer. Such an analysis cannot be undertaken here. Some perspective on monetary developments during 1972-73 may be gained, however, from comparisons with the experience of other industrial countries, and by recalling briefly how domestic economic conditions evolved during this period.

Table III compares the growth of $\mathrm{M}_{1}$ in the United States with that of other industrial countries in 1972 and the first half of 1973. The definitions of $\mathrm{M}_{1}$ differ somewhat from country to country, but are as nearly comparable as statistical sources permit. It goes without saying that each country faced its own set of economic conditions and problems. Yet it is useful to note that monetary growth in the United States was much lower than in other major industrial countries, and that it also was steadier than in the other countries.

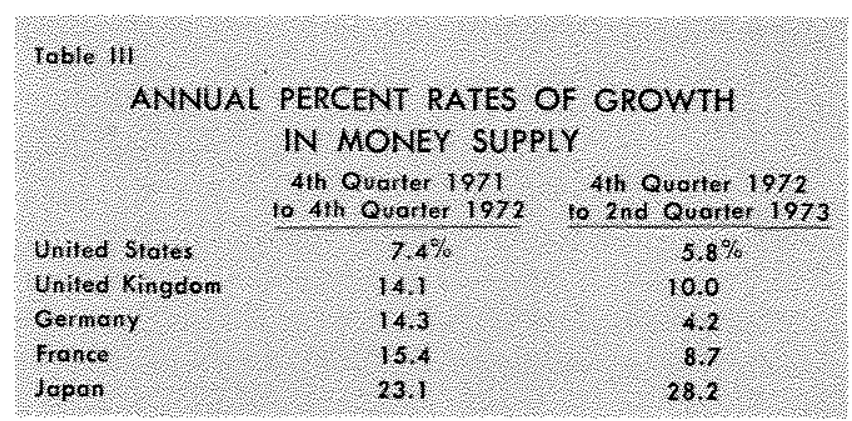

The next table shows, in summary fashion, the rates of change in the money supply of the United States, in its total production, and in the consumer price level during 1972 and 1973. The table is based on the latest data. It may be noted, in passing, that, according to data available as late as January 1973 , the rate of growth of $M_{1}$ during 1972 was 7.2 percent, not 7.4 percent; and that the rate of increase in real GNP was 7.7 percent, not 7.0 percent. In other words, on the basis of the data available during 1972, the rate of growth of $M_{1}$ was below the rate of growth of the physical volume of over-all production.

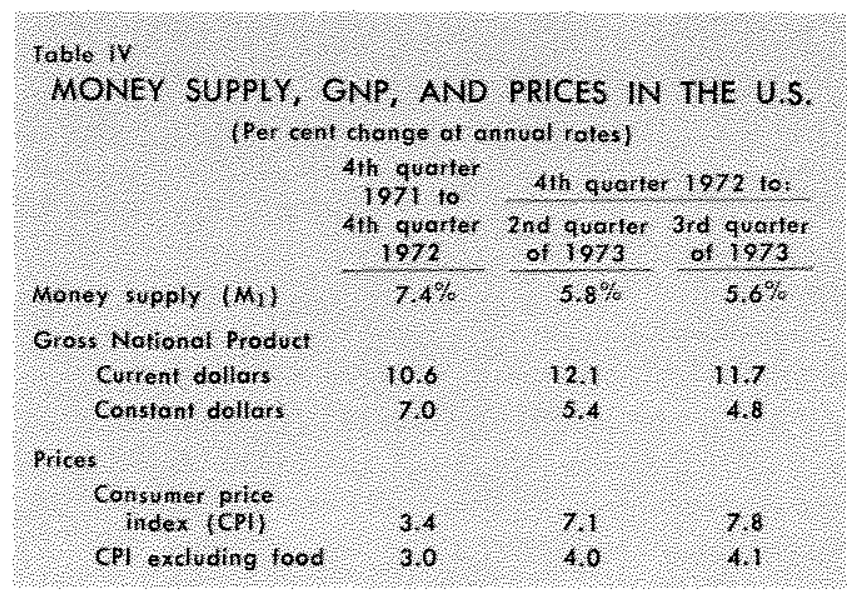

The table indicates that growth in $M_{1}$ during 1972 and 1973 approximately matched the growth of real output, but was far below the expansion in the dollar value of the nation's output. Although monetary poIicy limited the availability of money relative to the growth of transactions demands, it still encouraged a substantial expansion in economic activity; real output rose by about 7 per cent in 1972. Even so, unemployment remained unsatisfactorily high throughout the greater part of the year. It was not until November that the unemployment rate dropped below 5.5 per cent. For the year as a whole, the unemployment rate averaged 5.6 per cent. It may be of interest to recall that unemployment averaged 5.5 per cent in 
1954 and 1960, which are commonly regarded as recession years.

Since the expansion of $M_{1}$ in 1972 was low relative to the demands for money and credit, it was accompanied by rising short-term interest rates. Long-term interest rates showed little net change last year, as credit demands were satisfied mainly in the short-term markets.

In 1973, the growth of $\mathrm{M}_{1}$ moderated while the transactions demands for cash and the turnover of money accelerated. GNP in current dollars rose at a 12 per cent annual rate as prices rose more rapidly. In credit markets, short-term interest rates rose sharply further, while long-term interest rates also moved up, though by substantially less than short-term rates.

The extraordinary upsurge of the price level this year reflects a variety of special influences. First, there has been a world-wide economic boom superimposed on the boom in the United States. Second, we have encountered critical shortages of basic materials. The expansion in industrial capacity needed to produce these materials had not been put in place earlier because of the abnormally low level of profits between 1966 and 1971 and also because of numerous impediments to new investment on ecological grounds. Third, farm product prices escalated sharply as a result of crop failures in many countries last year. Fourth, fuel prices spurted upward, reflecting the developing shortages in the energy field. And fifth, the depreciation of the dollar in foreign exchange markets has served to boost prioes of imported goods and to add to the demands pressing on our productive resources.

In view of these powerful special factors, and the cyclical expansion of our economy, a sharp advance in our price level would have been practically inevitable in 1973. The upsurge of the price level this year hardly represents either the basic trend of prices or the response of prices to previous monetary or fiscal policies - whatever their shortcomings may have been. In particular, as the above tables show, the explosion of food prices that occurred this year is in large part responsible for the accelerated rise in the over-all consumer price level.

The severe rate of inflation that we have experienced in 1973 cannot responsibly be attributed to monetary management or to public policies more generally. In retrospect, it may well be that monetary policy should have been a little less expansive in
1972. But a markedly more restrictive policy would have led to a still sharper rise in interest rates and risked a premature ending of the business expansion, without limiting to any significant degree this year's upsurge of the price level.

\section{Concluding Obserwations}

The present inflation is the most serious economic problem facing our country, and it poses great difficulties for economic stabilization policies. We must recognize, I believe, that it will take some time for the forces of inflation, which now engulf our economy and others around the world, to burn themselves out. In today's environment, controls on wages and prices cannot be expected to yield the benefits they did in 1971 and 1972, when economic conditions were much different. Primary reliance in dealing with inflation both in the near future and over the longer term will have to be placed on fiscal and monetary policies.

The prospects for regaining price stability would be enhanced by improvements in our monetary and fiscal instruments. The conduct of monetary policy could be improved if steps were taken to increase the precision with which the money supply can be controlled by the Federal Reserve. Part of the present control problem stems from statistical inadequacies chiefly the paucity of data on deposits at nonmember banks. Also, however, control over the money supply and other monetary aggregates is less precise than it can or should be because nonmember banks are not subject to the same reserve requirements as are Federal Reserve members.

I hope that the Congress will support efforts to rectify these deficiencies. For its part, the Federal Reserve Board is even now carrying on discussions with the Federal Deposit Insurance Corporation about the need for better statistics on the nation's money supply. The Board also expects shortly to recommend to the Congress legislation that will put demand deposits at commercial banks on a uniform basis from the standpoint of reserve requirements.

Improvements in our fiscal policies are also needed. It is important for the Congress to put an end to fragmented consideration of expenditures, to place a firm ceiling on total Federal expenditures, and to relate these expenditures to prospective revenues and the nation's economic needs. Fortunately, there is now widespread recognition by members of the Congress of the need to reform budgetary procedures along these broad lines. 
It also is high time for fiscal policy to become a more versatile tool of economic stabilization. Particularly appropriate would be fiscal instruments that could be adapted quickly, under special legislative rules, to changing economic conditions - such as a variable tax credit for business investment in fixed capital. Once again, I would urge the Congress to give serious consideration to this urgently needed reform.

We must strive also for better understanding of the effects of economic stabilization policies on economic activity and prices. Our knowledge in this area is greater now than it was five or ten years ago, thanks to extensive research undertaken by economists in academic institutions, at the Federal Reserve, and elsewhere. The keen interest of the Joint Economic Committee in improving economic stabilization polim cies has, I believe, been an influence of great importance in stimulating this widespread research effort.

I look forward to continued cooperation with the Committee in an effort to achieve the kind of economic performance our citizens expect and deserve.

Sincerely yours,

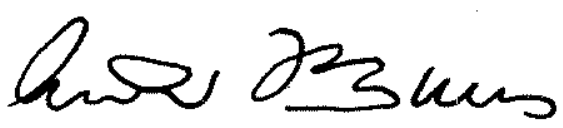

Arthur F. Bunns

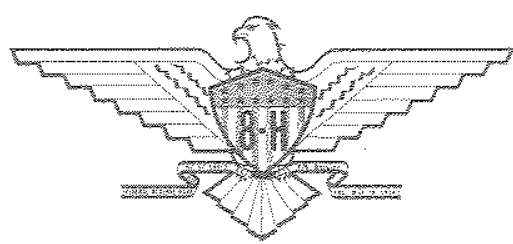

